\title{
Comparison of heavy metals contamination and ecological risk between soils enriched with compost and chemical fertilizers in the North of Iran and ecological risk assessment
}

\author{
Abdoliman Amouei $^{1,2}{ }^{\circledR}$, Hourieh Fallah ${ }^{1,2}{ }^{\circledR}$, Hosseinali Asgharnia $^{1,2^{*}}{ }^{\circledR}$, Abbas Mousapour $^{3^{(}}, \operatorname{Hadi} \operatorname{Parsian}^{4^{\circledR}}$, \\ Mahmoud Hajiahmadi $^{4}{ }^{\mathbb{D}}$, Asieh Khalilpour $^{1,2}{ }^{\mathbb{D}}$, Hajar Tabarinia $^{5}$ \\ ${ }^{1}$ Environmental Health Research Center (EHRC), Health Research Institute, Babol University of Medical Sciences, Babol, Iran \\ ${ }^{2}$ Social Determinants of Health Research Center, Health Research Institute, Babol University of Medical Sciences, Babol, Iran \\ ${ }^{3}$ Department of Biochemistry, School of Medicine, Babol University of Medical Sciences, Babol, Iran \\ ${ }^{4}$ Cancer Research Center, Health Research Institute, Babol University of Medical Sciences, Babol, Iran \\ ${ }^{5}$ Department of Environmental Health Engineering, School of Public Health, Babol University of Medical Sciences, Babol, Iran
}

\begin{abstract}
Background: Nowadays, uncontrolled use of chemical fertilizers in agriculture is one of the reasons for the entry of heavy metals into the environment. In this study, the heavy metals contamination of the soils enriched with compost and chemical fertilizers in the North of Iran and its ecological risk assessment were evaluated.

Methods: In this study, 108 soil samples were collected from agricultural soils of some places of Babol in Mazandaran province. An atomic absorption spectrophotometer (PG-990) was used to determine the concentrations of lead, cadmium, and zinc in the soil samples. The assessment of soil contamination was performed by the contamination factor, degree of contamination indices, and the potential ecological risk of the heavy metals. Data were analyzed using SPSS version 22. Descriptive and chi-square tests were used to compare the mean with existing standards. Significant level was considered at $P<0.05$. Results: The highest lead concentration $(35.7 \pm 9.5 \mathrm{mg} / \mathrm{kg})$ was observed at $5-\mathrm{cm}$ depth, and the maximum cadmium $(1.1 \pm 0.2 \mathrm{mg} / \mathrm{kg})$ and zinc $(88 \pm 22.6 \mathrm{mg} / \mathrm{kg})$ concentrations were observed at 15 - $\mathrm{cm}$ depth. The results showed that lead, cadmium, and zinc concentrations in the agricultural soils enriched with compost fertilizers were acceptable, but agricultural soils enriched with chemical fertilizers indicated higher content than those enriched with compost fertilizers and higher than the maximum allowable concentration. The maximum contamination degree, pollution index, and potential ecological risk in the agricultural soils enriched with the chemical fertilizers were 15.77, 1.97, and 293.48, respectively, and these soils had low potential pollution and moderate ecological risks.

Conclusion: According to the results, it is necessary to use compost fertilizers for the agricultural soils enrichment.

Keywords: Heavy metals, Ecological risk assessment, Agricultural soils, Compost and chemical fertilizers

Citation: Amouei A, Fallah H, Asgharnia H, Mousapour A, Parsian H, Hajiahmadi M. Comparison of heavy metals contamination and ecological risk between soils enriched with compost and chemical fertilizers in the North of Iran and ecological risk assessment. Environmental Health Engineering and Management Journal 2020; 7(1): 7-14. doi: 10.34172/EHEM.2020.02.
\end{abstract}

Article History: Received: 13 September 2019 Accepted: 7 December 2019 ePublished: 17 January 2020

\section{Introduction}

Soil is an important element of nature that is exposed to various pollutions such as heavy metals $(1,2)$. In general, heavy metal contamination of soil comes from natural and human sources. In natural source, which refers to the natural nature of the earth, heavy metals of the rocks enter the soil through erosion of water, wind, weathering, and atmospheric precipitation (3).

Soil contamination with heavy metals caused by human activities include the discharge of industrial plating and melting effluent $(4,5)$, urban sewage sludge and agricultural drainage containing heavy metals (6), as well as the high consumption of chemical fertilizers and pesticides, increase the soil pollution of the world $(7,8)$. The main concern about heavy metals is that they are not metabolized in the body and accumulate in the fat tissues, muscles, bones, and joints, resulting in numerous diseases and complications $(9,10)$. The effects of heavy metals on 
human beings are different, the most important of which is the development of neurological disorders, carcinogenesis, genetic disorders, and complications of bearing abnormal child (11). Cadmium is one of the most widely distributed metals in the environment. The main source of this metal is chemical compounds derived from plating and melting industry in addition to phosphate fertilizers consumed in agriculture (12). This metal is easily absorbed by the plants and has high toxicity. This toxic metal accumulates in tissues like liver and kidneys, causing lung and prostate cancers, arthritis and bone pains, anemia, and increased blood pressure in humans $(6,13)$. Lead $(\mathrm{Pb})$ can cause side effects, such as abnormal hemoglobin synthesis and anemia, hypertension, kidney damage, abortion, nervous system disorders, brain damage, child's decreased ability of learning and behavioral disorders in children, such as aggression and hyperactivity (14).

Azimzadeh and Khademi investigated the background concentration of some heavy metals in agricultural soils in different parts of Mazandaran province. In this study, the natural and manmade background concentrations of $\mathrm{Pb}$, cadmium $(\mathrm{Cd})$, zinc $(\mathrm{Zn})$, copper $(\mathrm{Cu})$, and nickel were $0.23,34.2,40.2,28.3$, and 45.7; and 0.23, 54.1, 49.5, 31.6, and 45.8, respectively (15). Parente et al studied heavy metals $(\mathrm{Pb}, \mathrm{Cd}, \mathrm{Cr}, \mathrm{Zn}, \mathrm{Cu}, \mathrm{Mn}$ ) concentrations in the soils enriched with poultry fertilizers in Rio de Janeiro upland region and evaluated the potential ecological risks in these soils (16). In another research, Srinivasa Gowd et al evaluated the contamination of heavy metals $(\mathrm{Pb}, \mathrm{Cr}$, $\mathrm{Zn}, \mathrm{Sr}$ ) in the soils of Ganga plain, Uttar Pradesh, India. They assessed heavy metals contamination in the soils based on the geoaccumulation index, enrichment and contamination factors, and degree of contamination (17). Mazandaran province and Babol are among the important agricultural poles in Iran. Agricultural products, especially fruits and vegetables, are exported from the city to other parts of the country. The amount of urea and phosphate fertilizers used in the agricultural areas of this city is 13000 and 4000 tons per year, respectively $(15,18)$.

Since agricultural soils can be a way to transport heavy metals into the human body, it is necessary to assess the heavy metals contamination level of agricultural soil. This study was conducted to investigate the concentration of heavy metals in the soils enriched with compost and chemical fertilizers in Babol (Mazandaran province) and to assess their contamination factors and potential ecological risks.

\section{Materials and Methods}

Babol, a city located in the Northern Iran with a population more than 1000000 , is the most populous city in Mazandaran province. The height of the city is $2 \mathrm{~m}$ below the open seas. Babol is located at latitude and longitude of $20^{\prime} 44^{\prime} 52^{\circ}$ and $15^{\prime} 24^{\prime} 36^{\circ}$, respectively. The mean annual rainfall and temperature of the city are $799 \mathrm{~mm}$ and $17.1^{\circ} \mathrm{C}$, respectively. The city has many rivers, especially the Babel
River, which flow into the Caspian Sea (17). Samples were collected from agricultural soils of the Eastern, Western, and Southern regions of Babol, Mazandaran province, in the Northern Iran (Figure 1) in the winter and summer of 2017. Totally, 108 soil samples were randomly collected from the studied regions. Any soil sample (approximately $1 \mathrm{~kg}$ ) was taken from a surface area of $20 \mathrm{~cm} \times 20 \mathrm{~cm}$ at $5-\mathrm{cm}$ and $15-\mathrm{cm}$ depths, and transferred to the laboratory using polyethylene bags. The soil samples were first airdried at room temperature for 1 week, and then, passed through a $2-\mathrm{mm}$ and $0.15-\mathrm{mm}$ sieve, respectively, for a two-stage chemical analysis $(18,19)$.

Analysis of heavy metals in soil samples

The concentration of $\mathrm{Pb}, \mathrm{Cd}$, and $\mathrm{Zn}$ in each soil sample was measured at specific wavelengths $(\mathrm{Pb}=2383.5 \mathrm{~nm}, \mathrm{Cd}$ $=288.8 \mathrm{~nm}$, and $\mathrm{Zn}=13.29 \mathrm{~nm})(16,19)$. To control the quality of the analyses, three blank samples were prepared along with other samples. Stock standard solutions of $\mathrm{Cd}, \mathrm{Zn}$, and $\mathrm{Pb}$ were provided at a concentration of 1000 $\mathrm{mg} / \mathrm{L}$ in a solution containing $0.5 \mathrm{M} \mathrm{HNO}_{3}$ (ultrapure) supplied by Merck (Germany). Only deionized water was used to prepare solutions for analysis. The final dilution of standard solutions was done by $0.5 \mathrm{M} \mathrm{HNO}_{3}\left(\mathrm{HNO}_{3}\right.$ $65 \%)$. This dilution of nitric acid $\left(\mathrm{HNO}_{3}\right)$ was also used as the zero-setting solution for calibration. This process was done to match the acid matrix of standards with samples. The calibration curve was established using the standard solutions $(19,20)$.

\section{Instruments}

In thisstudy, a PG990atomicabsorption spectrophotometer equipped with deuterium background correction, and $\mathrm{Cd}, \mathrm{Zn}$, and $\mathrm{Pb}$ hollow-cathode lamps as the radiation source, was used. The operating parameters were set as recommended by the manufacture. Atomic absorption measurement was carried out in an air-acetylene flame. The acetylene flow rate and burner height were adjusted

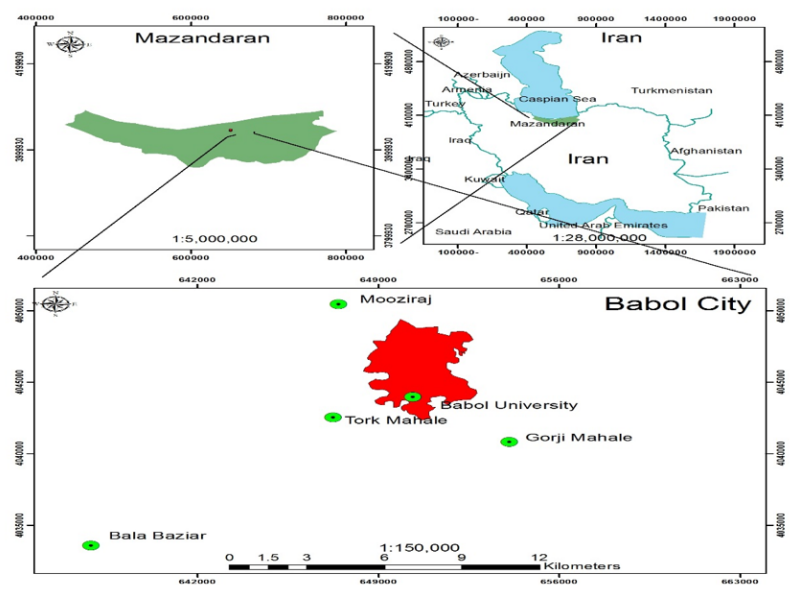

Figure 1. The location of Babol in the world and the location of sampling sites (S1= Bala Baziar; S2= Gorji Mahale; S3= Mooziraj). 
in order to obtain the maximum absorption signals while aspirating the analyte solution containing $0.5 \mathrm{M} \mathrm{HNO}_{3}$.

\section{Analytical characteristics}

For instrumental conditions used, the analytical detection limit was $0.0028,0.012$, and $0.003 \mathrm{mg} / \mathrm{L}$ for $\mathrm{Cd}, \mathrm{Pb}$, and $\mathrm{Zn}$, respectively. The sensitivity, standard deviation (SD), and precision of analytical condition were evaluated. Fiveto-eight-point calibration curves were prepared for each element with aspiration of the standard solutions (1-1.5 $\mathrm{mL}$ ). Analysis of each sample was carried out three times with integration time of 3 seconds to obtain a relatively standard deviation of $5 \%$ or less within the calibration range. $\mathrm{Zn}, \mathrm{Cd}$, and $\mathrm{Pb}$ concentrations were determined using a deuterium background correction. In this study, 6 working standard solutions were obtained for $\mathrm{Zn}(0.00$, $0.5,1,2,4$, and $6 \mathrm{mg} / \mathrm{L}), 7$ standard solutions for $\mathrm{Pb}(0.00$, $0.312,0.625,1.25,2.5,5$, and $10 \mathrm{mg} / \mathrm{L})$, and 8 standard solutions for $\mathrm{Cd}(0.00,0.018,0.039,0.078,0156,0.312$, 0.625 , and $1.25 \mathrm{mg} / \mathrm{L})$, which were prepared from the standard stock solution (1000 $\mathrm{mg} / \mathrm{L})$ purchased from Merck (Germany). Serial dilutions were carried out and acidified using nitric acid 2\%. Analytical characteristics of elements are shown in Table 1. Data were analyzed using SPSS version 22. Descriptive and chi-square tests were used to compare the mean with existing standards. Statistical significant level was considered at $P<0.05$.

Determination of contamination factor $\left(\mathrm{C}_{\mathrm{f}}\right)$ and degree of contamination $\left(\mathrm{C}_{\mathrm{deg}}\right)$

The assessment of soil contamination is performed by the contamination factor $\left(\mathrm{C}_{\mathrm{f}}\right)$ and degree of contamination $\left(\mathrm{C}_{\mathrm{deg}}\right)$ indices. The $\mathrm{C}_{\mathrm{f}}^{\mathrm{i}}$ of a metal is determined by the following equation:

$\mathrm{C}_{\mathrm{f}}^{\mathrm{i}}=\frac{C_{m}^{i}}{C_{n}^{i}}$

Where $C_{m}{ }^{i}$ is mean concentration of metals $(\mathrm{mg} / \mathrm{kg})$ and $C_{n}{ }^{i}$ is the natural concentration of individual element (background level) $(\mathrm{mg} / \mathrm{kg})$.

The $C_{f}^{i}$ is the single element index and the sum of contamination factors for all metals is indicated by the $\mathrm{C}_{\text {des }}$ of the location. The degree of contamination is classified into four classes $(20,21)$ :

1. $\mathrm{C}_{\mathrm{deg}}<8=>$ Low degree of contamination

2. $8<\mathrm{C}_{\mathrm{deg}}<16=>$ Moderate degree of contamination

3. $16<\mathrm{C}_{\mathrm{deg}}<32=>$ Considerable degree of contamination

4. $\mathrm{C}_{\mathrm{deg}}>32=>$ Very high degree of contamination
Evaluation of pollution index (PI)

The pollution level of a metal is determined by the single pollution index $\left(\mathrm{PI}_{\mathrm{i}}\right)$. $\mathrm{PI}_{\mathrm{i}}$ is calculated using the following equation:

$\mathrm{PI}_{\mathrm{i}}=\frac{\mathrm{C}_{\mathrm{i}}}{\mathrm{S}_{\mathrm{i}}}$

Where $C_{i}$ is a metal concentration in a soil sample $(\mathrm{mg} / \mathrm{kg})$ and $S_{i}$ is the reference value $(\mathrm{mg} / \mathrm{kg})$.

The total potential pollution of the soils by the heavy metals was evaluated by the Nemerow integrated pollution index (NIPI).

$\mathrm{NIPI}=\sqrt{\frac{\mathrm{PI}_{\mathrm{ave}+\mathrm{PI}_{\mathrm{imax}}^{2}}^{2}}{2}}$

Where $P I_{\text {ave }}$ and $P I_{\text {imax }}$ are the average and maximum of the pollution indices for individual metals, respectively. The NIPI is categorized: 1) NIPI $<0.7=>$ non-pollution; 2) $0.7<\mathrm{NIPI}<1=>$ warning line of pollution; 3 ) $1<\mathrm{NIPI}<2$ $=>$ low level of pollution; 4) $2<\mathrm{NIPI}<3=>$ moderate level of pollution; and 5) NIPI $>3=>$ high level pollution (22).

Estimation of the potential ecological risk

The potential ecological risk of heavy metal in the soils was evaluated using the ecological risk index (RI) $(15,22)$. The RI index was determined by the sum of risk factors of the metals:

$\mathrm{RI}=\sum_{i=1}^{n} \mathrm{Er}^{\mathrm{i}}$

Where $E r^{i}$ is the risk factor of any metal, and is determined using Eq. (5):

$\operatorname{Er}^{\mathrm{i}}=\operatorname{Tr}^{\mathrm{i}} \times \mathrm{Cf}^{\mathrm{i}}=\operatorname{Tr}^{\mathrm{i}} \frac{\mathrm{C}_{\mathrm{i}}}{\mathrm{B}_{\mathrm{i}}}$

Where $\mathrm{Ti}$ is the toxic-response factor for any metal. The Toxic-response values of $\mathrm{Pb}, \mathrm{Cd}$, and $\mathrm{Zn}$ were 5,30 , and 1 , respectively. And $C_{f}^{i}$ is the metal contamination factor calculated from the measured concentration $\left(\mathrm{C}_{\mathrm{i}}\right)$ and the background concentration $\left(\mathrm{B}_{\mathrm{i}}\right)$ of the metal $(\mathrm{mg} / \mathrm{kg})$.

\section{Results}

Analysis of the collected data displayed that the mean and highest concentrations of $\mathrm{Cd}(0.7$ and $0.9 \mathrm{mg} /$ $\mathrm{kg}$ ) were found in the Western Babol (S3) and the soils enriched with chemical fertilizers (Figure 2). The lowest

Table 1. Hollow-cathode lamps conditions and flame conditions in flame atomic absorption spectrometry

\begin{tabular}{lcccccc}
\hline \multirow{2}{*}{ Element } & Wavelengths $(\mathrm{nm})$ & Lamp current (mA) & Relativity of SD & Detection Limit (mg/L) & \multicolumn{2}{c}{ Flow Rate of Flame Gases (I/min) } \\
\cline { 4 - 7 } & 228.8 & 7 & 0.997 & Air & 0.0028 & 0.6 \\
$\mathrm{Cd}$ & 217.0 & 4 & 0.995 & 0.012 & 0.7 \\
$\mathrm{~Pb}$ & 213.9 & 5 & 0.995 & 0.003 & 1.8 & 0.7 \\
$\mathrm{Zn}$ & & & & & 1.5 \\
\hline
\end{tabular}


Table 2. The characteristics of the agricultural soil samples in the studied places

\begin{tabular}{|c|c|c|c|c|c|c|c|c|c|c|c|}
\hline \multirow{2}{*}{ Sample } & \multirow{2}{*}{ Horizon } & \multirow{2}{*}{ Depth $(\mathrm{cm})$} & \multirow{2}{*}{$\mathrm{EC}(\mathrm{ds} / \mathrm{m})$} & \multirow{2}{*}{$\mathrm{pH}$} & \multirow{2}{*}{$\begin{array}{l}\text { Soil texture } \\
\text { class }\end{array}$} & \multicolumn{3}{|c|}{ Soil texture(\%) } & \multirow{2}{*}{$\begin{array}{l}\text { Organic } \\
\text { carbon }\end{array}$} & \multirow{2}{*}{$\begin{array}{c}\mathrm{CaCO}_{3} \\
(\%)\end{array}$} & \multirow{2}{*}{$\begin{array}{c}\text { Soil humidity } \\
\text { (\%) }\end{array}$} \\
\hline & & & & & & Silt & Sand & Clay & & & \\
\hline 1 & Ap & $0-20$ & 0.92 & 7.6 & S.L & 20 & 61 & 19 & 0.83 & 5.5 & 42 \\
\hline 2 & B1 & $20-60$ & 0.50 & 7.7 & $\mathrm{~L}$ & 33 & 43 & 24 & 0.27 & 6.7 & 55 \\
\hline 3 & B2 & $60-150$ & 0.52 & 7.6 & $\mathrm{~L}$ & 37 & 37 & 26 & 0.27 & 12.2 & 72 \\
\hline
\end{tabular}

concentration of Cd $(0.1 \mathrm{mg} / \mathrm{kg})$ was found in S1 location and the soil enriched with compost fertilizer (Figure 2). Table 2 shows the properties of the agricultural soil samples in the studied areas. According to this table, $61 \%$ of the soil texture in the surface area $(1-20 \mathrm{~cm})$ is sand and soil texture class is sand- loam. Also the soil $\mathrm{pH}$ is slightly alkaline and moisture content is more than $40 \%$. The mean and highest concentrations of $\mathrm{Pb}$ (35.5 and 63.8 $\mathrm{mg} / \mathrm{kg}$ ) were found in the Western region (S3) and soil enriched with chemical fertilizer (Figure 3). Moreover, the minimum concentration of $\mathrm{Pb}(13.2 \mathrm{mg} / \mathrm{kg})$ was observed in S1 location and the soils enriched with compost organic fertilizer. The mean and highest concentrations of $\mathrm{Zn}$ (70.5 and $95.8 \mathrm{mg} / \mathrm{kg}$ ) were found in S3 location and the soils enriched with chemical fertilizer (Figure 4). The minimum concentration of $\mathrm{Zn}(23.5 \mathrm{mg} / \mathrm{kg})$ was found in the Eastern region (S2) and the soils enriched with compost organic fertilizer (Figure 4).

The results obtained from the mean concentration of heavy metals in the studied areas and their comparison with the allowable concentrations of these metals in Iran and other countries showed that the $\mathrm{Pb}$ and $\mathrm{Zn}$ contents are less than the maximum allowable concentration of contaminant. However, the mean concentration of $\mathrm{Cd}$ in

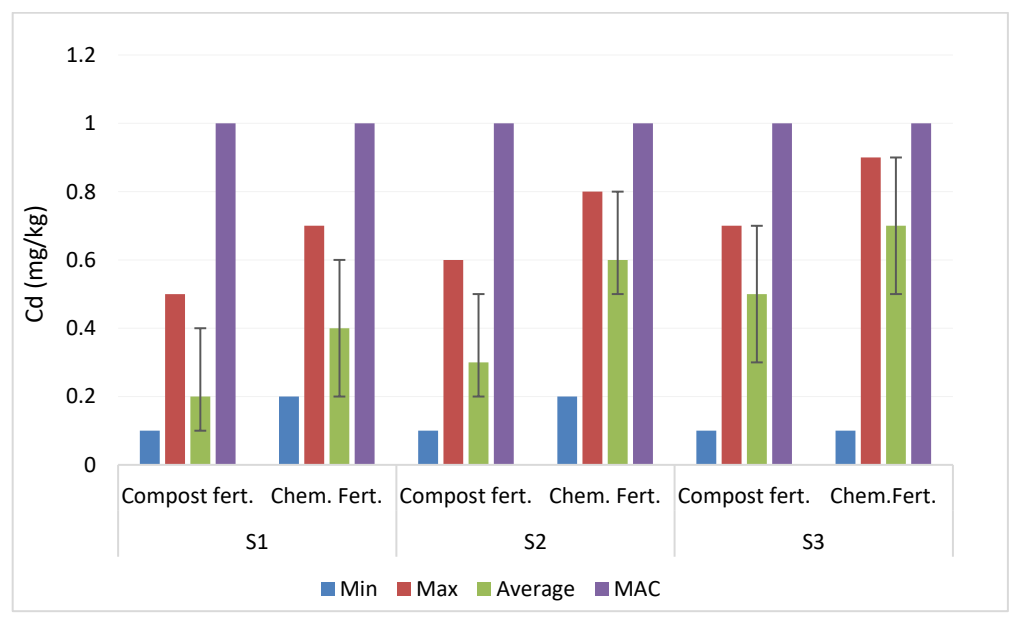

Figure 2. The minimum, maximum, average, and maximum allowable concentrations of cadmium in the agricultural soil samples of various areas with different fertilizers at a 5 -cm depth.

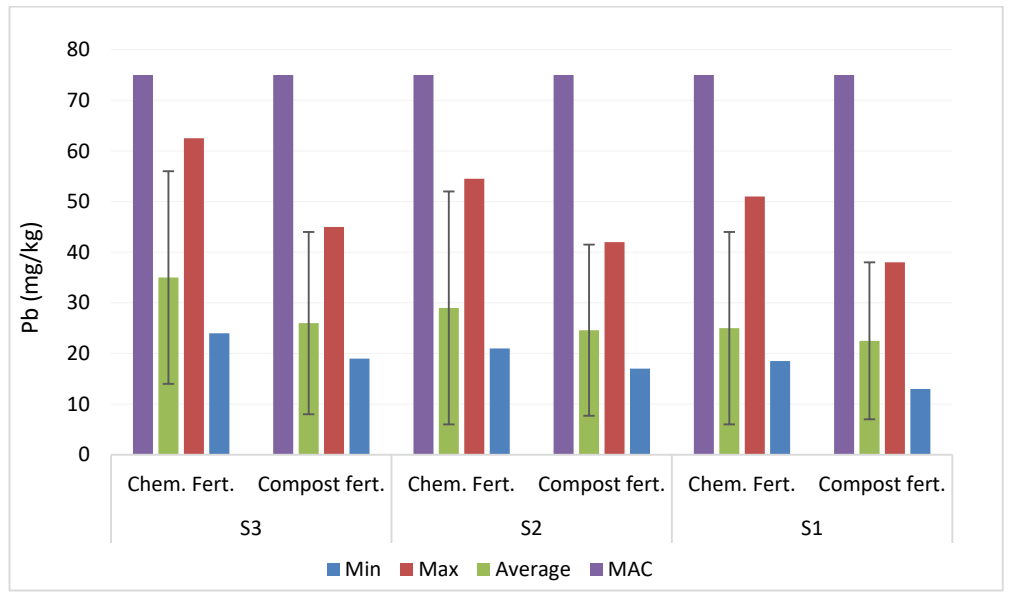

Figure 3. The minimum, maximum, average, and maximum allowable concentrations of lead in the agricultural soil samples of various areas with different fertilizers at a $5-\mathrm{cm}$ depth 


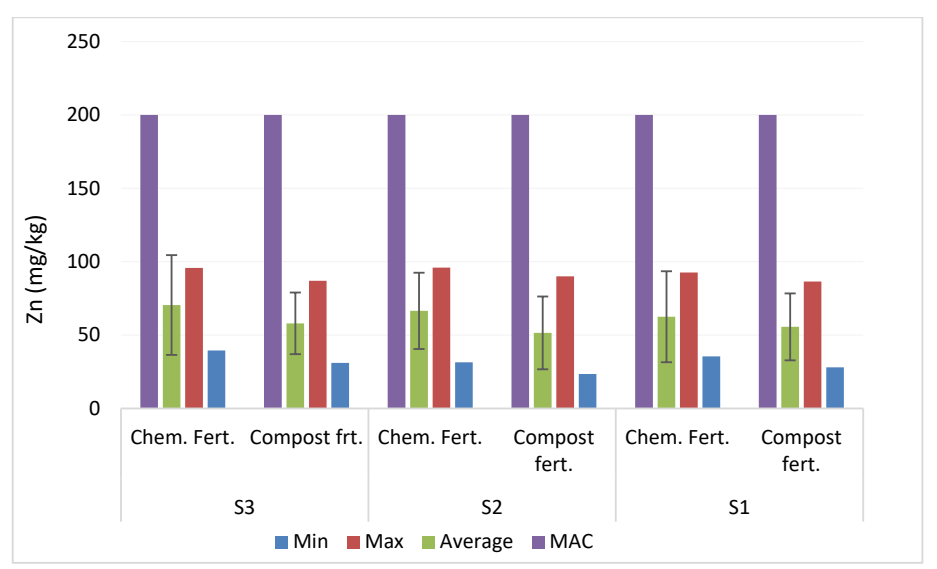

Figure 4. The minimum, maximum, average, and maximum allowable concentrations of zinc in the agricultural soil samples of various areas with different fertilizers at a 5-cm depth.

the soils enriched with chemical fertilizers is near to the national and global standards (Table 3 ).

Evaluation of the heavy metals concentration illustrated that the highest concentration of $\mathrm{Cd}, \mathrm{Pb}$, and $\mathrm{Zn}(0.9$, 62.5 , and $95.8 \mathrm{mg} / \mathrm{kg}$ ) in the enriched soils with chemical fertilizers at a $5-\mathrm{cm}$ depth was found in S3 location. Statistical tests represented that there was a difference between the mean concentrations of $\mathrm{Cd}, \mathrm{Pb}$, and $\mathrm{Zn}$ in the agricultural soils of the studied regions, but this difference was not significant $(P$ value $=0.08,0.07$ and 0.06$)($ Table 4$)$. The mean concentrations of $\mathrm{Pb}, \mathrm{Zn}$, and $\mathrm{Cd}$ at different depths of agricultural soils in different regions illustrated that the highest concentrations of $\mathrm{Pb}$ were related to all locations at a 5 -cm depth and the maximum concentration of $\mathrm{Cd}$ and $\mathrm{Zn}$ in different locations was associated to 15- cm depth (Table 5).

As shown in Table 5, there was no significant difference between mean $\mathrm{Pb}$ concentration in the agricultural soils and soil depth. However, there was a significant difference between mean concentrations of $\mathrm{Zn}$ and $\mathrm{Cd}$ at depths of 5 and $15 \mathrm{~cm}(P=0.02)$ (Table 5). The mean and highest amounts of the NIPI of the soils enriched with compost and chemical fertilizers were 1.20 and $1.44 ; 1.64$ and 1.97, respectively, and belonged to S3 location (Table 6).

Table 7 shows the contamination level and ecological risk factors of the selected metals in the soil samples enriched with compost and chemical fertilizers. Maximum $\mathrm{C}_{\mathrm{f}}$ of $\mathrm{Cd}, \mathrm{Pb}$, and $\mathrm{Zn}$ in the soils enriched with compost were determined to be $5.67,1.44$, and 3.22 , respectively, and in the soils enriched with chemical fertilizer were obtained

Table 3. Comparison of heavy metals contents in the agricultural soil samples with global standards

\begin{tabular}{|c|c|c|c|c|c|c|c|}
\hline \multirow{2}{*}{ Metal } & \multicolumn{3}{|c|}{ Heavy Metals Concentrations (mg/kg) } & \multicolumn{4}{|c|}{ Maximum Level Concentration (mg/kg) (23-24) } \\
\hline & Minimum & Maximum & Mean \& SD & Iran & China & American & Australia \\
\hline $\mathrm{Pb}$ & 13 & 62.30 & $35.2 \pm 10.50$ & 75 & 80 & 200 & 300 \\
\hline $\mathrm{Zn}$ & 22.5 & 95.80 & $70.50 \pm 25$ & 500 & $200-300$ & 1100 & 200 \\
\hline $\mathrm{Cd}$ & 0.10 & 0.90 & $0.70 \pm 0.20$ & 1 & $0.30-0.60$ & 0.48 & 3 \\
\hline
\end{tabular}

Table 4. Mean concentration of heavy metals in the soil samples $(n=108)$ in different regions at a $5-\mathrm{cm}$ depth

\begin{tabular}{|c|c|c|c|}
\hline Metal & Different Region & Mean \& SD (mg/kg) & $P$ value \\
\hline \multirow{4}{*}{$\mathrm{Pb}$} & $\mathrm{S} 1$ & $25.90 \pm 19$ & \multirow{4}{*}{0.074} \\
\hline & $\mathrm{S} 2$ & $29 \pm 18$ & \\
\hline & S3 & $34.80 \pm 21$ & \\
\hline & Mean & $29.90 \pm 19.30$ & \\
\hline \multirow{4}{*}{$\mathrm{Zn}$} & $\mathrm{S} 1$ & $66.50 \pm 31$ & \multirow{4}{*}{0.06} \\
\hline & $\mathrm{S} 2$ & $62.7 \pm 26$ & \\
\hline & S3 & $70.50 \pm 34$ & \\
\hline & Mean & $66.57 \pm 30$ & \\
\hline \multirow{4}{*}{$\mathrm{Cd}$} & S1 & $0.40 \pm 0.20$ & \multirow{4}{*}{0.08} \\
\hline & $\mathrm{S} 2$ & $0.60 \pm 0.10$ & \\
\hline & S3 & $0.70 \pm 0.20$ & \\
\hline & Mean & $0.57 \pm 0.30$ & \\
\hline
\end{tabular}


Table 5. Concentration of heavy metals in different locations at depths of 5 and $15 \mathrm{~cm}$

\begin{tabular}{|c|c|c|c|c|c|c|c|}
\hline \multirow{4}{*}{ Metal } & \multicolumn{7}{|c|}{ Mean \pm SD $(\mathrm{mg} / \mathrm{kg})$} \\
\hline & \multicolumn{6}{|c|}{ Location } & \multirow{3}{*}{$P$ value } \\
\hline & \multicolumn{2}{|c|}{ S1 } & \multicolumn{2}{|c|}{ S2 } & \multicolumn{2}{|c|}{ S3 } & \\
\hline & $5 \mathrm{~cm}$ & $15 \mathrm{~cm}$ & $5 \mathrm{~cm}$ & $15 \mathrm{~cm}$ & $5 \mathrm{~cm}$ & $15 \mathrm{~cm}$ & \\
\hline $\mathrm{Pb}$ & $25.90 \pm 19$ & $20 \pm 15$ & $29 \pm 18$ & $23.80 \pm 20$ & $34.80 \pm 21$ & $26.5014 \pm$ & $P=0.45$ \\
\hline Zn & $66.50 \pm 31$ & $81.50 \pm 21$ & $62.70 \pm 26$ & $76.50 \pm 19$ & $70.50 \pm 34$ & $9223 \pm$ & $P=0.02$ \\
\hline $\mathrm{Cd}$ & $0.40 \pm 0.20$ & $0.60 \pm 0.30$ & $0.60 \pm 0.10$ & $0.80 \pm 0.40$ & $0.70 \pm 0.20$ & $0.900 .30 \pm$ & $P=0.02$ \\
\hline
\end{tabular}

Table 6. The pollution index of heavy metals in the soils enriched with compost and chemical fertilizers

\begin{tabular}{|c|c|c|c|c|c|c|c|c|}
\hline Location & $\mathrm{PI}_{\mathrm{Pb} \text { compost }}$ & $\mathbf{P I}_{\text {Cd compost }}$ & $\mathrm{PI}_{\text {Zn compost }}$ & NIPI ${ }_{\text {compost }}$ & $\mathrm{PI}_{\mathrm{Pb} \text { chemical }}$ & $\mathrm{PI}_{\text {Cd chemical }}$ & $\mathrm{PI}_{\mathrm{Zn} \text { chemical }}$ & $\mathrm{NIPI}_{\text {chemical }}$ \\
\hline S1 & 0.6 & 0.66 & 1.15 & 0.98 & 0.68 & 1.33 & 1.26 & 1.21 \\
\hline S2 & 0.67 & 1 & 1.21 & 1.19 & 0.79 & 2 & 1.40 & 1.73 \\
\hline S3 & 0.73 & 1.65 & 1.20 & 1.44 & 0.96 & 2.33 & 1.34 & 1.97 \\
\hline Mean & 0.67 & 1.10 & 1.19 & 1.20 & 0.81 & 1.89 & 1.33 & 1.64 \\
\hline Standard Deviation & 0.15 & 0.70 & 0.12 & 0.87 & 0.20 & 0.65 & 0.46 & 0.71 \\
\hline
\end{tabular}

Table 7. Estimation of the contamination factor and the potential ecological risk in the soil samples $(n=72)$ enriched with compost and chemical fertilizers

\begin{tabular}{|c|c|c|c|c|c|c|c|c|c|c|c|}
\hline \multirow{3}{*}{ Soil Type } & \multirow{3}{*}{ Location } & \multicolumn{10}{|c|}{ Contamination \& Risk Assessment Indexes } \\
\hline & & \multicolumn{5}{|c|}{$C_{f}$} & \multicolumn{5}{|c|}{$\mathrm{Er}_{\mathrm{i}}$} \\
\hline & & Cd & $\mathrm{Pb}$ & $\mathrm{Zn}$ & $C_{\text {deg }}$ & Contamination Degree & Cd & $\mathrm{Pb}$ & $\mathrm{Zn}$ & $\mathbf{R} \mathbf{I}$ & Risk Degree \\
\hline \multirow{6}{*}{$\begin{array}{l}\text { Compost } \\
\text { fertilizer }\end{array}$} & S1 & 2.66 & 0.62 & 2.59 & 5.87 & Low & 80 & 3.08 & 2.60 & 85.68 & Low \\
\hline & $\mathrm{S} 2$ & 3.66 & 0.67 & 2.63 & 6.96 & Low & 100 & 3.37 & 2.63 & 106 & Low \\
\hline & S3 & 4 & 0.75 & 2.78 & 7.53 & Low & 120 & 3.77 & 2.78 & 126.55 & Low \\
\hline & Max & 5.67 & 1.41 & 3.22 & 10.30 & Moderate & 170 & 7.05 & 3.22 & 180.27 & Moderate \\
\hline & Min & 1.33 & 0.36 & 2.21 & 3.90 & Low & 40 & 1.78 & 2.21 & 43.99 & Low \\
\hline & Mean & 3.44 & 0.68 & 2.66 & 6.79 & Low & 100 & 3.41 & 2.67 & 106.08 & Low \\
\hline \multirow{6}{*}{$\begin{array}{l}\text { Chemical } \\
\text { fertilizer }\end{array}$} & S1 & 6.33 & 1.07 & 2.88 & 10.28 & Moderate & 190 & 5.33 & 2.88 & 198.21 & Moderate \\
\hline & S2 & 5 & 1.16 & 2.95 & 9.11 & Moderate & 150 & 5.81 & 2.95 & 158.76 & Moderate \\
\hline & S3 & 5.67 & 1.25 & 3.47 & 10.39 & Moderate & 170 & 6.23 & 3.47 & 179.70 & Moderate \\
\hline & Max & 9.33 & 1.85 & 4.59 & 15.77 & Moderate & 280 & 9.25 & 4.59 & 293.84 & Moderate \\
\hline & Min & 3.67 & 0.81 & 2.53 & 7.01 & Low & 110 & 4.04 & 2.53 & \multirow{2}{*}{$\begin{array}{l}116.57 \\
178.89\end{array}$} & Low \\
\hline & Mean & 5.67 & 1.16 & 3.10 & 9.93 & Moderate & 170 & 5.79 & 3.10 & & Moderate \\
\hline
\end{tabular}

to be $9.33,1.85$, and 4.59 , respectively. The degree of contamination $\left(\mathrm{C}_{\mathrm{deg}}\right)$ of different locations (S1, S2, S3) in the soils enriched with compost fertilizer were 5.87, $6.96,7.53$, and 6.79 , respectively, and in the soils fertilized with chemical fertilizer, were 10.28, 9.11, 10.39, and 9.93, respectively. The maximum $\mathrm{C}_{\mathrm{deg}}$ in the soils enriched with compost and chemical fertilizers were 10.30 and 15.77, respectively.

\section{Discussion}

The results of measurement of the concentration of heavy metals in the soil of the studied regions indicated that among the three studied metals $(\mathrm{Pb}, \mathrm{Zn}$, and $\mathrm{Cd})$, the mean concentration of $\mathrm{Cd}$ in both seasons was higher than the standard value of Iran, China, and the United States $(1 \mathrm{mg} / \mathrm{kg})(16,22)$. Cd, which is easily absorbed through the root and creates toxicity in the food chain, is undoubtedly the most important pollutant in agricultural soils and plant products (16). Nevertheless, since the concentration of $\mathrm{Cd}$ is not high in the natural soils of the studied regions, Cd contamination in the region cannot be attributed to natural factors, such as the soil and geology of the area or the water used to irrigate agricultural soils. Therefore, as mentioned in studies by Williams and David (23), Schipper et al (24), and Salmanzadeh et al (25), the use of chemical fertilizers can lead to Cd contamination in some soil samples, so that the mean concentration of $\mathrm{Cd}$ is higher in soils enriched with chemical fertilizers 
than those enriched with compost fertilizers. In a study by Parizanganeh et al, the concentrations of $\mathrm{Pb}, \mathrm{Cd}, \mathrm{Zn}$, $\mathrm{Cu}$, cobalt, and nickel in the agricultural topsoil of Bonab region in Zanjan province were determined 58.18, 1.4, $299.31,67.68,18.53$, and $28.11 \mathrm{mg} / \mathrm{kg}$, respectively (26). Ghorbani et al reported the concentrations of $\mathrm{Cd}, \mathrm{Pb}$, $\mathrm{Zn}, \mathrm{Cr}$, and $\mathrm{Cu}$ in the agricultural soils of some places in Golestan province as $0.18,13.05,70.06,60.68$, and 22.99 $\mathrm{mg} / \mathrm{kg}$, respectively (27). The most important reason for this difference between the metals is due to reduced dissolution and low mobility of $\mathrm{Pb}$ compounds in the soil so that the $\mathrm{Pb}$ released in the soil is fixed in the layers of the soil and does not penetrate into the underlying layers of the soil (28). In contrast, $\mathrm{Zn}$ and Cd compounds have high solubility and mobility in the soil, so that these metals gradually transfer from the surface layers to the deep layers of the soil $(29,30)$.

Ecological risk factors are the most important parameters for the assessment of heavy metals effects in soils on human beings and environment $(31,32)$. In this study, the maximum and mean ecological risk factors of $\mathrm{Cd}$, $\mathrm{Pb}$, and $\mathrm{Zn}$ in the soils enriched with chemical fertilizers was higher than those in the soils fertilized with compost fertilizers. The average value of the potential ecological risk of the heavy metals $(\mathrm{Cd}, \mathrm{Pb}$, and $\mathrm{Zn}$ ) in soils enriched with compost and chemical fertilizers were determined 106.08 and 178.89, respectively, indicating low and moderate ecological risk, respectively. The maximum ecological risk of the heavy metals was found in the soils fertilized with chemical fertilizer, which shows a considerable ecological risk. Ecological risk order of the heavy metals in the soils enriched with compost and chemical fertilizers was $\mathrm{Cd}$ $>\mathrm{Pb}>\mathrm{Zn}$, indicating that $\mathrm{Cd}$ is the most important risk factor. In the study of Liu et al, the potential ecological risk of the vegetables soils in the order of $\mathrm{Cd}>\mathrm{Pb}>\mathrm{Cu}$ $>\mathrm{Cr}>\mathrm{Zn}$ were determined (33). Sayadi et al assessed the potential ecological risk of $\mathrm{Pb}, \mathrm{Cd}, \mathrm{Cu}, \mathrm{Zn}$, and chrome in the agricultural topsoil of Amirabad district in Birjand. This study showed that the ecological risk of the heavy metals in the residential areas soils was high, but in the agricultural and livestock soils, it was low (34).

\section{Conclusion}

The levels of $\mathrm{Pb}$ and $\mathrm{Zn}$ in the soil were less than the standard value due to the lack of industrial factories in the region. Nevertheless, the use of chemical fertilizers led to the gradual accumulation of heavy metals in the soil. The results of the present study represented that the concentration of the studied metals was according to the national standards, but the concentration of heavy metals in the agricultural soils enriched with chemical fertilizers was high. In addition, the contamination factors and potential ecological risks in the soils enriched with chemical fertilizers were higher than those in the soils enriched with compost fertilizers. Thus, it is recommended to use compost organic fertilizers for enriching agricultural soils.
In addition, the results suggested that the concentration of $\mathrm{Pb}$ was higher in the surface layers than deep layers while the concentrations of $\mathrm{Cd}$ and $\mathrm{Zn}$ were higher in deep layers than surface layers of the soil.

\section{Acknowledgments}

The authors would like to appreciate the Vice-Chancellor of Research and Technology in Babol University of Medical Sciences for its financial and spiritual support.

\section{Ethical issues}

The authors certify that this manuscript is the original work of the authors, all data collected during the study are presented in this manuscript, and no data from the study has been or will be published separately.

\section{Competing interests}

The authors declare that they have no conflict of interests.

\section{Authors' contributions}

All authors contributed equally and participated in the data collection, analysis, and interpretation. All authors critically reviewed, refined, and approved the manuscript.

\section{References}

1. Liu Y, Su C, Zhang H, Li X, Pei J. Interaction of soil heavy metal pollution with industrialisation and the landscape pattern in Taiyuan city, China. PLoS One 2014; 9(9): e105798. doi: 10.1371/journal.pone.0105798.

2. Wei B, Yang L. A review of heavy metal contaminations in urban soils, urban road dusts and agricultural soils from China. Microchem J 2010; 94(2): 99-107. doi: 10.1016/j. microc.2009.09.014.

3. Morton-Bermea O, Hernández-Álvarez E, GonzálezHernández G, Romero F, Lozano R, Beramendi-Orosco LE. Assessment of heavy metal pollution in urban topsoils from the metropolitan area of Mexico City. J Geochem Explor 2009; 101(3): 218-24. doi: 10.1016/j.gexplo.2008.07.002.

4. Rascio N, Navari-Izzo F. Heavy metal hyperaccumulating plants: how and why do they do it? and what makes them so interesting? Plant Sci 2011; 180(2): 169-81. doi: 10.1016/j. plantsci.2010.08.016.

5. Qi Y, Huang B, Darilek JL. Effect of drying on heavy metal fraction distribution in rice paddy soil. PLoS One 2014; 9(5): e97327. doi: 10.1371/journal.pone.0097327.

6. Zhang H, Cui B, Xiao R, Zhao H. Heavy metals in water, soils and plants in riparian wetlands in the Pearl River Estuary, South China. Procedia Environ Sci 2010; 2: 134454. doi: 10.1016/j.proenv.2010.10.145.

7. Sahu SC. Editorial: nanotoxicology and nanomedicine: a special issue of the food and chemical toxicology. Food Chem Toxicol 2015; 85: 1. doi: 10.1016/j.fct.2015.07.014.

8. Lawley R, Curtis L, Davis J. The Food Safety Hazard Guidebook. UK: RSC Publishing; 2012.

9. Salar-Amoli J, Ali-Esfahani T. Determination of hazardous substances in food basket eggs in Tehran, Iran: a preliminary study. Vet Res Forum 2015; 6(2): 155-9.

10. Ziarati P, Moslehisahd M. Determination of Heavy Metals 
$(\mathrm{Cd}, \mathrm{Pb}, \mathrm{Ni})$ in Iranian and Imported Rice Consumed in Tehran. Iranian Journal of Nutrition Sciences \& Food Technology 2017; 12(2): 97-104. [In Persian].

11. Tahsini H, Gavilian H. Assessment risk food of heavy metals (cadmium, lead, zinc and copper) from the consumed crops have been distributed in Santandaj. Zanko 2016; 17(54): 6272. [In Persian].

12. Cui H, Shi Y, Zhou J, Chu H, Cang L, Zhou D. Effect of different grain sizes of hydroxyapatite on soil heavy metal bioavailability and microbial community composition. Agriculture Ecosystems \& Environment 2018; 267: 165-73. doi: 10.1016/j.agee.2018.08.017.

13. Khan S, Cao Q, Zheng YM, Huang YZ, Zhu YG. Health risks of heavy metals in contaminated soils and food crops irrigated with wastewater in Beijing, China. Environmental Pollution 2008; 152(3): 686-92. doi: 10.1016/j. envpol.2007.06.056.

14. Bhuiyan MA, Parvez L, Islam MA, Dampare SB, Suzuki S. Heavy metal pollution of coal mine-affected agricultural soils in the northern part of Bangladesh. J Hazard Mater 2010; 173(1-3): 384-92. doi: 10.1016/j.jhazmat.2009.08.085.

15. Azimzadeh B, Khademi H. Estimation of background concentration of selected heavy metals for pollution assessment of surface soils of Mazandaran province, Iran. Journal of Water and Soil 2013; 27(3): 548-59. [In Persian].

16. Parente CE, Lino AS, Arruda Junior ER, Zonta E, Dorneles PR, Torres JPM, et al. Multi-temporal accumulation and risk assessment of available heavy metals in poultry litter fertilized soils from Rio de Janeiro upland region. Environ Monit Assess 2018; 191(1): 28. doi: 10.1007/s10661-0187156-7.

17. Srinivasa Gowd S, Ramakrishna Reddy M, Govil PK. Assessment of heavy metal contamination in soils at Jajmau (Kanpur) and Unnao industrial areas of the Ganga Plain, Uttar Pradesh, India. J Hazard Mater 2010; 174(1-3): 11321. doi: 10.1016/j.jhazmat.2009.09.024.

18. Soleimannejad Z, Abdolzadeh A, Sadeghipour HR. Heavy metal concentrations in industrial area soils and landfill site, Ghaemshahar, Iran. Journal of Mazandaran University of Medical Sciences 2016; 26(136): 196-201. [In Persian].

19. APHA, AWWA, WEF. Standard Methods for Water and Wastewater Examinations. 22th ed. Washington, DC: APHA, AWWA, WEF; 2012.

20. Amouei AI, YousefiZ, Mahvi AH, NaddafiK, Tahmasbizadeh M. Heavy metal concentrations in industrial, agricultural, and highway soils in northern Iran. Environ Justice 2012; 5(3): 153-57. doi: 10.1089/env.2011.0038.

21. He Z, Shentu J, Yang X, Baligar VC, Zhang T, Stoffella PJ. Heavy metal contamination of soils: sources, indicators and assessment. Journal of Environmental Indicators 2015; 9: 17-8.

22. Amouei AI, Cherati A, Naghipour D. Heavy metals contamination and risk assessment of surface soils of Babol in northern Iran. Health Scope 2018; 7(1): e62423. doi: 10.5812/jhealthscope.62423.
23. Williams $\mathrm{CH}$, David DJ. The accumulation in soil of cadmium residues from phosphate fertilizers and their effect on the cadmium content of plants. Soil Science 1976; 121(2): 86-93.

24. Schipper LA, Sparling GP, Fisk LM, Dodd MB, Power IL, Littler RA. Rates of accumulation of cadmium and uranium in a New Zealand hill farm soil as a result of long-term use of phosphate fertilizer. Agric Ecosyst Environ 2011; 144(1): 95-101. doi: 10.1016/j.agee.2011.08.002.

25. Salmanzadeh M, Balks MR, Hartland A, Schipper LA. Cadmium accumulation in three contrasting New Zealand soils with the same phosphate fertilizer history. Geoderma Reg 2016; 7(3): 271-8. doi: 10.1016/j.geodrs.2016.05.001.

26. Parizanganeh AH, Bijnavand V, Zamani AA, Hajabolfath A. Concentration, distribution and comparison of total and bioavailable heavy metals in top soils of Bonab district in Zanjan province. Open J Soil Sci 2012; 2(2): 123-32. doi: 10.4236/ojss.2012.22018.

27. Ghorbani H, Hafezi Moghadas N, Kashi H. Effects of land use on the concentrations of some heavy metals in soils of Golestan province, Iran. J Agric Sci Technol 2015; 17: 102540.

28. Qing X, Yutong Z, Shenggao L. Assessment of heavy metal pollution and human health risk in urban soils of steel industrial city (Anshan), Liaoning, Northeast China. Ecotoxicol Environ Saf 2015; 120: 377-85. doi: 10.1016/j. ecoenv.2015.06.019.

29. Barzin M, Kheirabadi H, Afyuni M. An investigation into pollution of selected heavy metals of surface soils in Hamadan province using pollution index. Journal of Water and Soil Science 2015; 19(72): 69-80. doi: 10.18869/ acadpub.jstnar.19.72.7. [In Persian].

30. Chang CY, Yu HY, Chen JJ, Li FB, Zhang HH, Liu CP. Accumulation of heavy metals in leaf vegetables from agricultural soils and associated potential health risks in the Pearl River Delta, South China. Environ Monit Assess 2014; 186(3): 1547-60. doi: 10.1007/s10661-013-3472-0.

31. Zhang L, Liao Q, Shao S, Zhang N, Shen Q, Liu C. Heavy metal pollution, fractionation, and potential ecological risks in sediments from Lake Chaohu (Eastern China) and the surrounding rivers. Int J Environ Res Public Health 2015; 12(11): 14115-31. doi: 10.3390/ijerph121114115.

32. Huang S, Shao G, Wang L, Wang L, Tang L. Distribution and health risk assessment of trace metals in soils in the golden triangle of Southern Fujian province, China. Int J Environ Res Public Health 2018; 16(1). doi: 10.3390/ ijerph16010097.

33. Liu X, Song Q, Tang Y, Li W, Xu J, Wu J, et al. Human health risk assessment of heavy metals in soil-vegetable system: a multi-medium analysis. Sci Total Environ 2013; 463-464: 530-40. doi: 10.1016/j.scitotenv.2013.06.064.

34. Sayadi MH, Shabani M, Ahmadpour N. Pollution index and ecological risk of heavy metals in the surface soils of Amir-Abad Area in Birjand city, Iran. Health Scope 2015; 4(1): e21137. doi: 10.17795/jhealthscope-21137. 